\title{
Fungating Primary Locally Malignant Giant Cell Tumor Of Ulna -A Case Report
}

\author{
Shrestha B, Kumar P, Singh GK, Singh MP \\ Department of Orthopaedics, B.P. Koirala Institute of Health Science, Dharan, Nepal
}

\section{ABSTRACT}

A giant cell tumor with local aggressiveness and penetration of cartilage is quite rare. We present a case of fungating giant-cell tumor of lower end of the ulna with wrist involvement including penetration of cartilage and diaphysis. Involvement with all these characteristics, according to the literature reviewed, is the first case of its type. We are of the opinion that the fungation may be due to incision and drainage and delayed presentation at tertiary care centre

\section{Key Words: Fungating giant-cell tumor, lower end of ulna, local aggressiveness, penetration of cartilage}

\section{INTRODUCTION}

Giant-cell tumours of bone (GCTOB) are benign, locally aggressive, primary bone tumours first described by Coopert in 1818. ${ }^{1}$ They occur most commonly in the distal femur, proximal tibia and distal radius of skeletally mature patients. ${ }^{2}$ The distal radius is the third most common site of GCTOB, accounting for approximately $10 \%$ of the cases. ${ }^{2}$ Approximately six percent of the lesions involve the distal ulna, ${ }^{3}$ with involvement of the bones of the hand being rare, accounting for between two and four percent. ${ }^{4}$ Primary malignant giant-cell tumor is quite rare (about $1 \%$ of all the bony lesions). Perforation of cortex is found in approximately $25 \%$ of patients. However, penetration of articular cartilage by giant-cell tumor is rare in the absence of fracture. Fungating giant-cell tumor with local aggressiveness and penetration of cartilage being rare. ${ }^{5}$

\section{CASE REPORT}

A 25-year-old female noticed a rapidly progressive painful swelling on the distal end of the right forearm for 2 months. A local practitioner performed incision and drainage of the swelling, which had no pus. After a few days, it gradually started fungating and progressively increasing in size with continuous oozing from the surface. Clinically, it was a fleshy mass of about $10 \mathrm{~cm}$ x $10 \mathrm{~cm}$ with continuous oozing and looked aggressive. Radiograph revealed complete destruction of the distal

\author{
Correspondence: \\ Dr. Pankaj Kumar \\ Department of Orthopedics \\ Ramnandan Mandal \\ Dhanusha, Janakpurdham, Nepal \\ E-mail:drpankaj06@yahoo.co.in
}


ulna with perforation of the cartiligous end. Clinicoradiologically, it looked like a malignat tumor arising from the distal end of the ulna (Figure-1a, 1b). The lesion was curetted and a provisional diagnosis of giantcell tumor with local aggressiveness was made. The complete removal of the tumor mass along with the pseudo-capsule of the ulna (wide resection) with fusion of the wrist joint was carried out. The material was sent for histopathological examination which confirmed that it was a giant-cell tumor on gross examination, the excised tumor was as an expansile mass involving both the epiphyseal and metaphyseal part of the lower end of the ulna which had a residual thin rim of bone present, except on the medial aspect where there was destruction of bone with soft tissue extension of tumor and skin ulceration. The total lesion measured $8 \times 8 \times 4$ $\mathrm{cm}$. The cut surface was fleshy and grayish white with focal area of hemorrhage (Figure-2). Microscopy

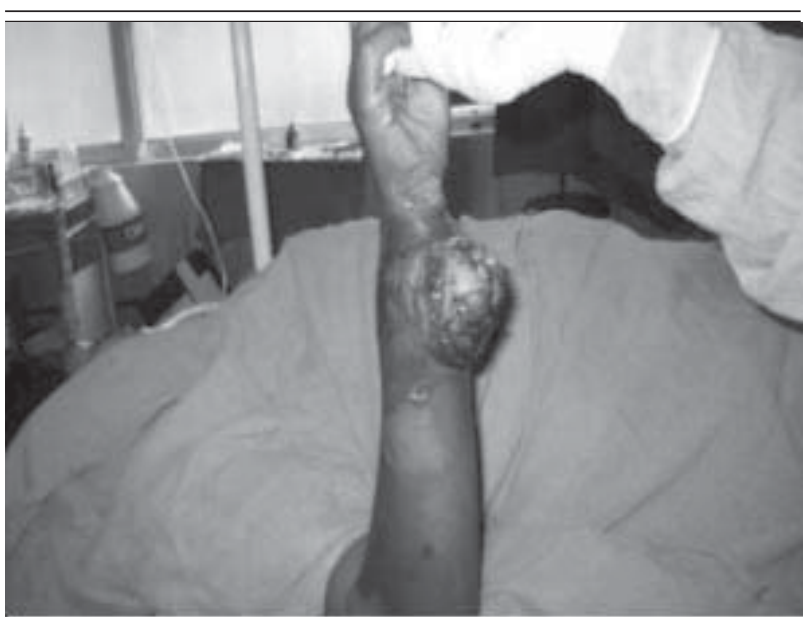

Figure 1 a. Showing clinical photograph with fungating mass

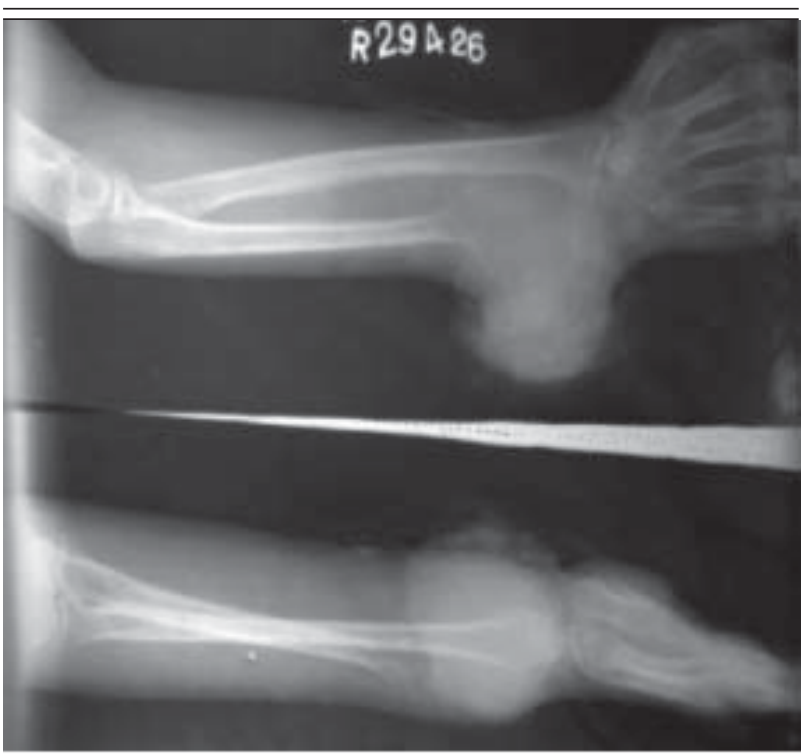

Figure $1 \mathrm{~b}$. Showing complete destruction of distal ulna with soft tissue extension

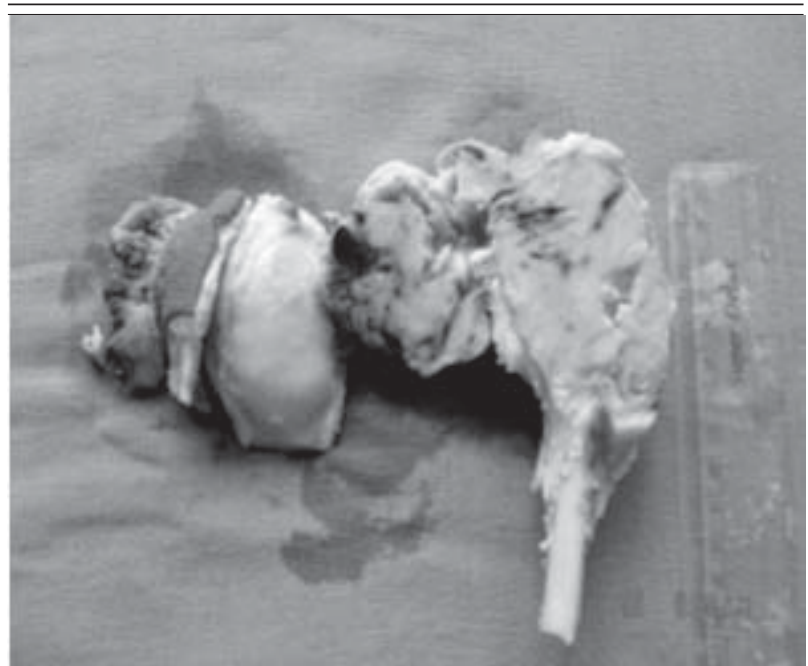

Figure 2. Showing excised tumor with cut surface fleshy and grayish white with focal area of hemorrhage

(200X H and E ) revealed features of classical giantcell tumor with the mononuclear (stromal) and giantcell components. The focal area showed preponderance of stromal cells with pleomorphism and mitotic activity (Figure- 3a, 3b).

After one year of follow-up, there was no evidence of reoccurrence at the local site and there was full range of motion at the elbow and hook, grip and pinch action was comparable with the other hand function. But the patient again reported after 3 years with a large swelling with mild to moderate pain and without a fungating mass. Biopsy again revealed (200X H and E I features of classical giant-cell tumor with the mononuclear (stromal) and giant-cell components. The focal area showed preponderance of stromal cells with pleomorphism and mitotic activity. An amputation from alone the elbow was performed.

\section{DISCUSSION}

Giant-cell tumors (GCT) of the bone (GCTOB) typically present in adults between the ages of 20 and 50 years with the symptoms of progressive pain and local swelling. Females are slightly more often affected than males. GCTs tend to arise in epiphyses of long tubular bones. The typical radiographic appearances are of geographical radiolucency and cortical thinning, without internal mineralization. GCTs represent $5 \%$ of all the primary bone tumors. Giant-cell tumor is not a tumor of the giant-cells. Giant-cell is reactive, the hence more the number of such cells, the better is the prognosis. The nature of the neoplastic stromal cell remains controversial. It is clearly mesenchymal rather than hemopoetic in nature. The ultra-structural features resemble those of a fibroblastic or osteoblastic nature. ${ }^{6}$ 


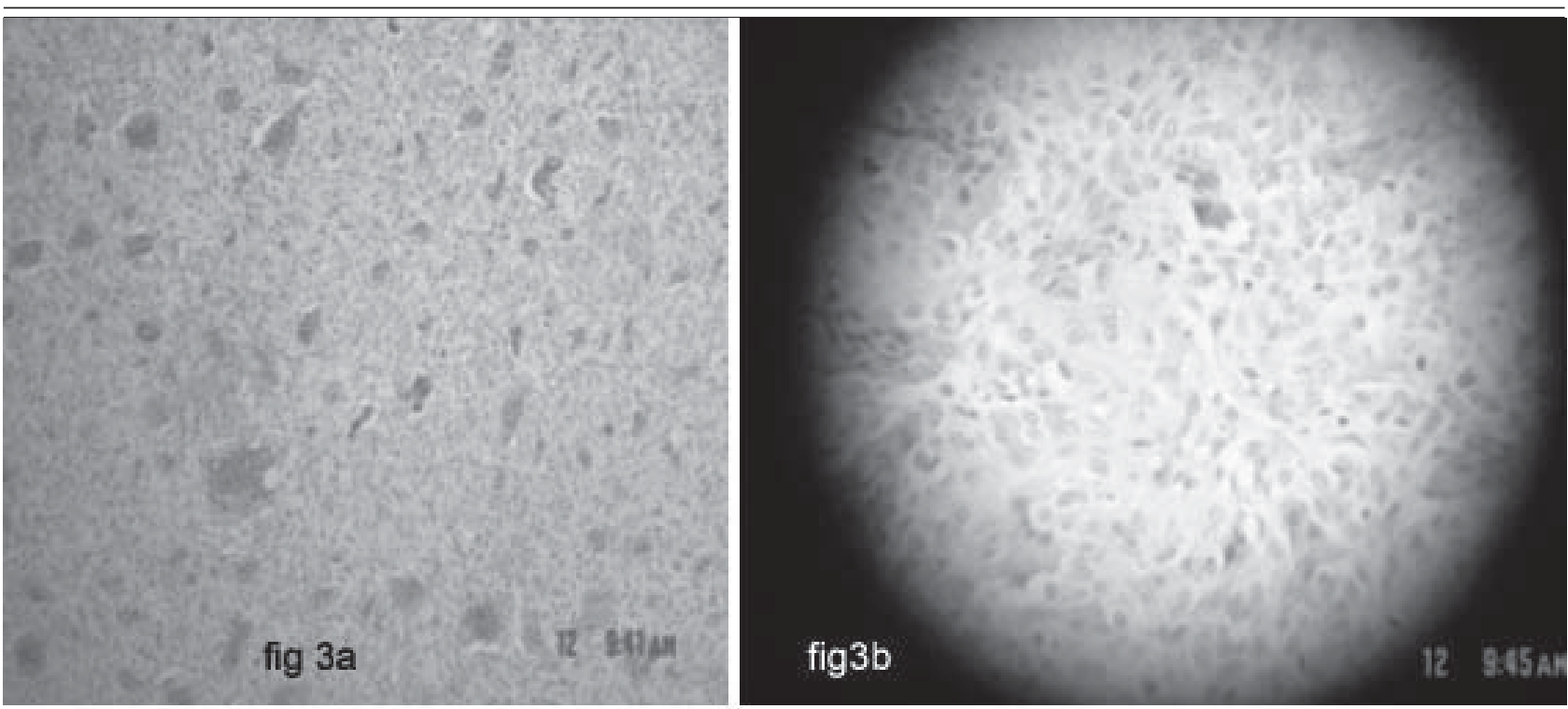

Figure $3 \mathrm{a}$ and $3 \mathrm{~b}$. Showing microscopy (200X $\mathrm{H}$ and $\mathrm{E})$ revealing features of classical giant-cell tumor with the mononuclear (stromal) and giant-cell component. Focal area show preponderance of stromal cells with pleomorphism and mitotic activity

The tumor usually respects anatomical boundaries, so being aggressive enough to cross the soft tissue and breach the skin and result in fungation is an extremely rare phenomenon. The cause of this needs further investigation and clarification but we were unable to establish any direct cause.

In 1971, Salm and Sissons described and illustrated 10 cases of giant-cell tumor of soft part (GCTSP) and distinguished this group of lesions from other giantcell-containing tumors. ${ }^{7}$ They based their histologic distinction on "numerous large multinucleated giant cells of osteoclast type, such that we are unable to distinguish them from giant-cell tumours of bone. The AFIP study was the first to recognize malignant behavior in GCTSP. They also noted that tumors in a superficial location had a relatively lower incidence of metastases than those located in the deep soft tissues. The presenting symptom is usually development of a mass over a relatively short duration. Interestingly, many of the masses are initially described as "hematomas" and a history of trauma is often given, as it was in our case.

\section{CONCLUSION}

This case report of a giant-cell tumor is a rare entity in terms of fungation, local aggressiveness, involvement lower end of ulna, wrist involvement including penetration of cartilage and diaphyseal involvement. With all these characteristics, this, according to the literature reviewed, is the first case of its type. We are in opinion that the fungation may be due to incision and drainage and delayed presentation at tertiary care centre.

\section{REFERENCES}

1. Eckardt JJ, Grogan TJ .Giant-cell tumor of bone. Clin Orthop, 1986; 204:45-58

2. Harness NG, Mankin HJ. Giantcell tumor of the distal forearm. J Hand Surg [Am] 2004; 29:188-193

3. Goldenberg RR, Campbell CJ, Bonfiglio M. Giant-cell tumor of bone. An analysis of two hundred and / eighteen cases. J Bone Jt Surg, [Am], 1970; 52:619-664

4. Averill RM, Smith RJ, Campbell CJ. Giant cell tumors of the bones of the hand. J Hand Surg [Am] ,1980; $5: 39-49$

5. WilsonSC, Ferdinand LM, Neitzschman HR.Radiological

case of the month.

Delayed treatment of a large, Fungating mass. Benign giant-cell tumor of bone; J

La state med soc. 1997 Oct; 149: 363-5

6. Aparisi T: Giant cell tumor of bone; Acta Oprthop Scand., 1978; 173 (Suppl.): 1-38

7. Salm R, Sissons HA. Giant-cell tumors of soft tissues. J Pathol 1972; 107:27-39.

8. Guccion JG, Enzinger FM. Malignant giant cell tumor of soft parts. An analysis of 32 cases. Cancer 1972; 29:1518-1529. 